\title{
Kineziologická analýza odrazu při běhu na lyžích dvoudobou střídavou klasickou technikou a oboustranným odvratem (stromečkem)
}

\author{
The reflection kinesiology analysis of cross country skiing - \\ classical technique diagonal stride and herring bone
}

\author{
Martina Chrástková, Petr 0. Novotný, Bronislav Kračmar \\ Univerzita Karlova, Fakulta tělesné výchovy a sportu, katedra sportů v př́rodě
}

\begin{abstract}
Abstrakt
Studie přináší srovnání vybraných koordinačních parametrů při dvou způsobech běhu na lyžích. Díky tvarové podobnosti prüběhu pohybu byl sledován běh na lyžích klasickou dvoudobou střídavou technikou a oboustranným odvratem (,,stromečkem“). Komparativní analýza se soustředila na odraz, který je rozhodujicí fází pro propulzi. Monitorována byla aktivace vybraných svalů dolních končetin ve fázi odrazu během sledovaných aktivit za použití povrchové polyelektromyografie se synchronizovaným akcelerometrem pro určení rozhraní mezi jednotlivými pracovními cykly.

Získaná data byla zpracována v SW MegaWin a MatLab, analyzována progresivní trojúhelníkovou metodou a porovnávána statistikou ANOVA1. Soubor sestával ze sedmi reprezentantů ČR v běhu na lyžích. Ze statistických výsledků Ize usuzovat na vysokou laterální intralokomoční podobnost klasické techniky (DS) i stromečku (HB) u všech probandů.

Teoretický prínos práce spatřujeme v objektivizaci prítomnosti (DS) nebo absence (HB) fáze skluzu, která se $v$ průběhu fylogeneze lokomoce živočišných druhů směřujících k rodu Homo nevyskytuje. Klasická technika se na rozdíl od výstupu stromečkem vyznačuje fází skluzu, čímž se vyčleňuje z prirozené lokomoce suchozemských obratlovců, a člověk se jí musí učit.
\end{abstract}

Klíčová slova: elektromyografie, běh na lyžích, odraz, aktivace svalů, fylogeneze lidské lokomoce

\section{Abstract}

The study brings the comparison of the representative coordination parameters during cross-country skiing - classic technique-diagonal stride and herringbone. There was watched the kick in the comparative analysis because the kick is determinative for propulsion. The activation of selected muscles on the legs during the skiing was monitored with surface electromyography. For the pinpoint of the boundary between two followed movement cycles, we used the synchronized accelerometer.

The gained data was processed by SW Mega Win and MatLab and analysed by the progressive triangle method and compared by ANOVA1. The monitored group was created by seven men who were members of Czech Cross-Country Ski Team.

Base on the monitored data we may presume the high level of the lateral similarity of cross-country skiing classic technique and herringbone as well. The base of significant differences in the muscles activation was found in the present the glide phase of movement cycle. The glide phase is very important during the diagonal stride cycle while the herringbone step is not contained any gliding. During human phylogenies, no animal uses any gliding so the gliding by the diagonal stride is not nature and the man have to learn it.

Keywords: kinesiology, EMG, electromyography, cross-country skiing, classical technique, herringbone, kick, reflection, muscle activation, phylogenesis of human locomotion 


\section{1 ÚVOD}

Přibližně čtyři tisíce let starou lidskou lokomocí na sněhové pokrývce je klouzavý pohyb na lyžích (Clifford, 1992). Efektivita tohoto pohybu je založena na tom, že lyže umožňují skluz, a usnadňují tak sestup, pohyb po rovině i výstup. Fylogeneticky vychází běh na lyžích z chůze a běhu. Odlišné charakteristiky oproti chůzi a běhu však vykazuje fáze opory při běhu na lyžích, kdy při chůzi a běhu je vytvořeno pevné punctum fixum $(\mathrm{PF})$ a oporná část chodidla setrvává na místě. Při běhu na lyžích v průběhu oporné fáze dochází ke skluzu a oporná fáze se tak mění ve fázi skluzu, která zvyšuje rychlost a efektivitu lokomoce. Zároveň však dochází k určitému posturálnímu dyskomfortu. Centrální nervový systém (CNS) skluz neboli smyk nevnímá primárně pozitivně (Kračmar, Chrástková, Bačáková, \& kol., 2016).

Při jízdě na běžeckých lyžích se jedná o relativně jednoduchý cyklický pohyb, který do činnosti zapojuje svalové partie celého těla: horní a dolní končetiny, trup i záda. Typickým znakem této formy lokomoce jsou opakující se pohyby horních a dolních končetin. Celá pohybová soustava se při běhu na lyžích nachází v dynamické rovnováze. Díky tomu, že je rovnoměrně zatížena celá pohybová soustava, nedochází $\mathrm{k}$ nadměrnému přetížení, a tím ani $\mathrm{k}$ poškození pohybového aparátu (Chrástková, 2014). Běh na lyžích začal být postupně využiván jako prostředek pro zábavu a sport a je ve své závodní formě olympijskou disciplínou. Dělí se na klasickou a volnou techniku (FIS, 2012; SLČR, 2013). Řadí se mezi dynamicky se rozvíjející sportovní disciplíny díky technicko-technologickému vývoji (výzbroj, výstroj i příprava tratí). I díky tomu se od 80. let 20. století rozvijí nová technika běhu na lyžích, kterou je bruslení na lyžích (Nilsson, Tveit, \& Eikrehagen, 2004). Za posledních 100 let vzrostla průměrná rychlost z $3,8 \mathrm{~m} \cdot \mathrm{s}^{-1}$ (1935) na dnešních $7 \mathrm{~m} \cdot \mathrm{s}^{-1}$. Došlo tak k nárůstu o $50 \%$. V porovnání s tím např. v plavání na $1500 \mathrm{~m}$ vzrostla rychlost o $40 \%$, v rychlobruslení o $20 \%$ a v běhu na $10 \mathrm{~km}$ o $12 \%$.

\section{METODIKA VÝZKUMU}

Cílem projektu bylo zjištění míry koordinační shody při dvou způsobech běhu na lyžích. Byla monitorována aktivace vybraných svalů dolních končetin ve fázi odrazu při běhu na lyžích střídavém dvoudobém klasickou technikou na lyžích různými technikami: stř́idavý běh dvoudobý klasickou technikou (diagonal stride - DS) vs. běh oboustranným odvratem (herringbone - HB). Výzkum experimentálního charakteru charakterizujeme jako komparativní analýzu fenoménů koordinačních intralokomočních změn.

\subsection{Soubor}

Sedm lyžařů běžců, reprezentantů ČR na Mistrovství světa juniorů a Mistrovství světa do 23 let 2013 v Liberci, v průměrném věku 19,9 let $( \pm 1,15)$. Nesledované proměnné byly hmotnost, výška, únava (díky malému počtu opakování, velmi nízkým nárokům na vitální funkce a vysokou výkonnost probandů).

\subsubsection{Parametry sledovaného pohybu}

Probandi absolvovali 30s úsek na spodní hranici anaerobního prahu (ANP; 80-85\% maximální tepové frekvence dle osobních testovacích zkušeností vrcholových sportovců) během dvoudobým střídavým (SD) a během oboustranným odvratem neboli stromečkem (HB) s dostatečnou délkou odpočinku (10 min). Lokalizaci intenzity zátěže v rámci rozmezí bazálního metabolismu versus anaerobní práh zvládli probandi naprosto spolehlivě díky zkušenostem z častého testování funkční zátěže vrcholových sportovců (dvakrát ročně). Kontrola úrovně metabolizmu byla prováděna indi- 
viduálně nastavenými sporttestery Polar v režimu měřič tepové frekvence s akustickým signálem při překročení stanovených prahů tepové frekvence.

\subsection{Sběr a analýza dat}

Sběr dat proběhl pomocí mobilního šestnáctikanálového EMG zařízení ME 6000 Biomonitor (Mega Electronics, Kuopio) s 14bit rozlišením a snímkovací frekvencí $1000 \mathrm{~Hz}$ s homologovanými samolepicími gelovými $\mathrm{Ag} / \mathrm{AgCl}$ elektrodami Medico Lead-lok s lokalizací dle protokolu SENIAM (2014) a MegaWin se synchronizovaným akcelerometrem a s použitím dvou videokamer.

Sběr dat proběhl na upravených lyžařských tratích v závodním areálu Břízky v Jablonci nad Nisou. Klimatické podmínky byly stálé, bezvětří, teplota vzduchu i sněhu $0{ }^{\circ} \mathrm{C}$. Byl zvolen padesátimetrový úsek terénu s rovnoměrným stoupáním $10^{\circ} \mathrm{s}$ počtem opakování pět s desetiminutovou přestávkou. Lyže probandů byly namazané optimálně zvolenými vosky pro danou sněhovou podmínku - vhodná varianta vosků byla konzultována s profesionálními servismany.

Dle výběru z předcházejícího pilotního výzkumu byly pro analýzu zvoleny svaly vykazující největší fenomény ohledně rozdílů timingu mezi oběma druhy běhu, a to bilaterálně: musculus (m.) peroneus longus (PL) sin. et dx., m. tibialis anterior (TA), sin. et dx. m. gastrocnemius, caput medialis (GM), sin et $\mathrm{dx}$.

EMG data byla analyzována a hodnocena v počítačových programech MegaWin a Matlab prostřednictvím segmentace signálu na jednotlivé periody pohybu (Špulák, 2015). Určení hranic jednotlivých pracovních kroků a klíčových míst pohybu bylo automaticky provedeno akcelerometrem synchronizovaným s EMG přistrojem. Hodnocený časový interval v rámci celého krokového cyklu byl určen dle následujících klíčových míst pohybu:

a) začátek: nástup významné aktivace kteréhokoliv ze sledovaných svalů, vážící se přímo $\mathrm{k}$ odrazu (Špulák \& kol., 2014),

b) konec: dosažení maximální hodnoty aktivace m. gastrocnemius, caput medialis, a tím dokončení odrazu.

Dle expertního posouzení byl pro analýzu a interpretaci naměřených dat vybrán časový úsek s vysokou periodicitou pracovních cyklů ošetřený od vzdálených dat (terénní nerovnosti, začátek a konec).

\subsection{Omezení analýzy pohybového cyklu na fázi odrazu}

Klíčovou fází pro běh na lyžích je odraz, při kterém je generována propulzní síla. Účinnost odrazu determinuje fázi skluzu, jejíž kvalita se odvijí i od jiných aspektů, jako jsou dynamická rovnováha, schopnost relaxace a další. Pokud odraz není proveden maximálně efektivně, fáze skluzu se zkracuje nebo k ní nedojde vůbec. Běh oboustranným odvratem (HB) skluzovou fázi dokonce postrádá, proto by analytická srovnávací studie celých lokomočních cyklů lokomoce se skluzem a lokomoce bez něj postrádala smysl (Chrástková, 2014).

Byly tak sledovány délky časových intervalů aktivace svalů před odrazem, zatímco m. tibialis anterior se v převážné většině případů (14) aktivuje až po dokončení odrazu. U tohoto svalu byl proto sledován časový úsek od odrazu k nástupu aktivace. Srovnání intervalů svalové práce bylo provedeno pomocí statistiky ANOVA1. Ostatní intervaly aktivace jsou zohledněny pouze pro doplňující kvalitativní hodnocení průběhu a charakteru svalové práce v rámci celého pracovního cyklu.

\subsection{Omezení platnosti}

Výsledky platí pro reprezentační tým ČR do 23 let, jehož členové se účastní světových soutěží a jejichž tréninkový proces využívá aktuálně progresivní světové metody. Tato skutečnost míru objektivity získaných výsledků zvyšuje. Díky předpokládané vysoké úrovni osvojené techniky 
pohybu lze výsledky využívat jako orientační s vysokou mírou pravděpodobnosti optimálního pohybového projevu modifikovaného individualitami probandů.

\section{VÝSLEDKY}

U všech probandů bylo dohromady hodnoceno průměrně 11,14 krokových cyklů techniky HB a 11,43 pro klasickou techniku DS (tabulka 1).

Tab. 1: Průměrný počet zpracovaných pohybových cyklů a průměrná délka pohybového cyklu včetně SD

\begin{tabular}{|c|l|c|}
\hline CL & Průměrný počet zpracovaných krokových cyklů & 11,43 \\
\hline & Průměrná délka krokového cyklu * ${ }^{-1}$ & 1,20 \\
\hline & SD * ${ }^{-1}$ & 0,11 \\
\hline HB & Průměrný počet zpracovaných krokových cyklů & 11,14 \\
\hline & Průměrná délka krokového cyklu * ${ }^{-1}$ & 0,81 \\
\hline & SD * ${ }^{-1}$ & 0,05 \\
\hline
\end{tabular}

Průměrný krokový cyklus trval 0,81 s (SD 0,05) u HB, 1,20 s (SD 0,08) pro DS. Podle velikosti směrodatné odchylky je $\mathrm{z}$ hlediska délky pohybového cyklu stabilnější lokomoce HB. Průměrné pohybové cykly obou druhů lokomoce byly pro potřeby komparativní analýzy časově normalizovány převedením na ordinální škálu.

V grafech Boats \& Envelopes konkrétního probanda P1 (obrázek 1 a obrázek 2) je bílým polem vyznačen interval odrazu, který byl z pohledu na svalovou aktivaci hodnocen následovně:

Boats (úsečky) vyjadřují interval významné aktivity měřených svalů $\mathrm{v}$ rámci průměrného kroku. Nejslabší úsečka na koncích vyjadřuje velikost směrodatné odchylky, a tedy míru periodicity cyklického pohybu. Středně silná úsečka odpovídá $2 \mathrm{SD}$, což je již uznávaná aktivace svalu dle zvolené metodiky (Špulák, 2015), nejsilnější úsečka pak vyjadřuje 3 SD. Světlý úsek mezi svislicemi vymezuje sledovaný interval odrazu dle definovaných klíčových míst pohybu: svislice v $0 \%$ vyznačuje okamžik dokončení odrazu, druhé dvě pak okamžik začátku významné aktivace prvního ze sledovaných svalů, která se přímo váže k odrazu.

Envelopes (spojitá křivka) představuje průběh EMG signálu průměrného pracovního cyklu u monitorovaných svalů při běhu na lyžích střídavém dvoudobém (DS) a při běhu na lyžích oboustranným odvratem (HB).

Monitorované svaly na pravé straně $(\mathrm{dx})$ a na levé straně $(\sin )$ :

- m. peroneus longus (PL),

- m. tibialis anterior (TA),

- m. gastrocnemius, caput medialis (GM). 


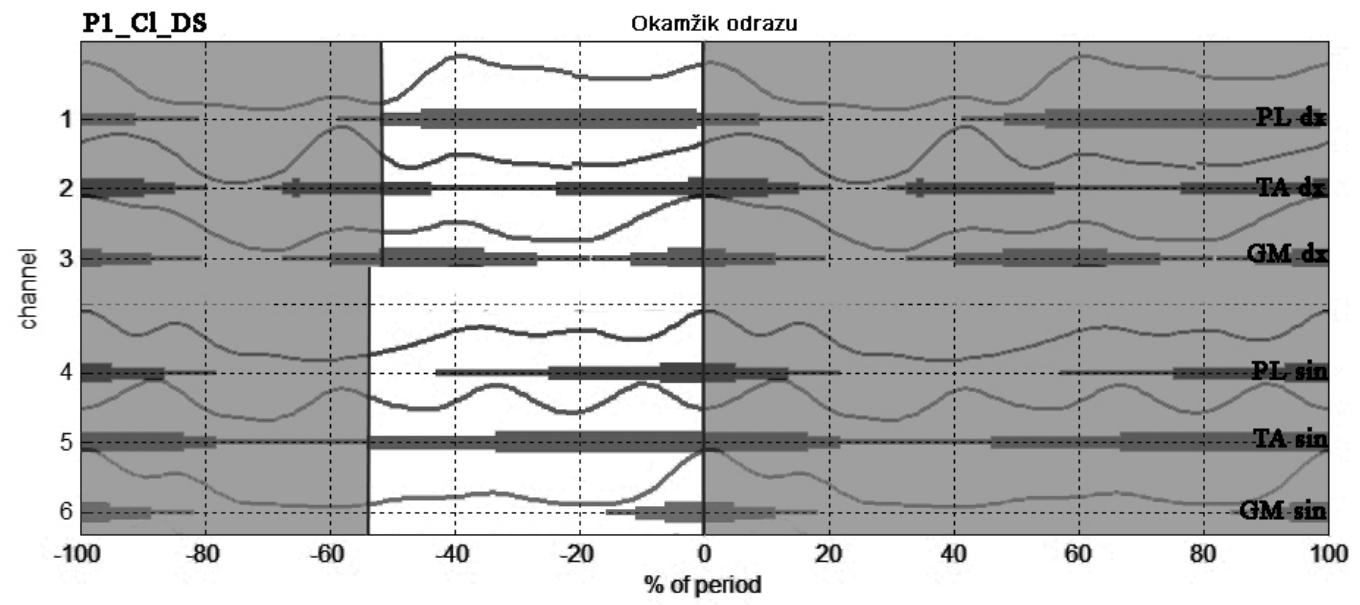

Obr. 1 Graf Boats \& Envelopes průměrného pracovního kroku, který ukazují intervaly významné svalové aktivity a průběh EMG křivky průměrného pracovního cyklu při DS u probanda $\mathrm{P} 1$ : Boats - vodorovné úsečky: nejslabší úsečka vyznačuje SD nástupu aktivace/deaktivace svalu; 2. a 3. vnitřní úsečka vyznačují interval uznatelné aktivity svalu. Envelopes - průběh EMG křivky průměrného pracovního cyklu. Kontinuální svislice vymezuji sledovaný interval odrazu dle definovaných klíčových míst pohybu: svislice v $0 \%$ vyznačuje okamžik dokončení odrazu, druhé dvě pak okamžik začátku významné aktivace prvního ze sledovaných svalů, která se prímo váže k odrazu.

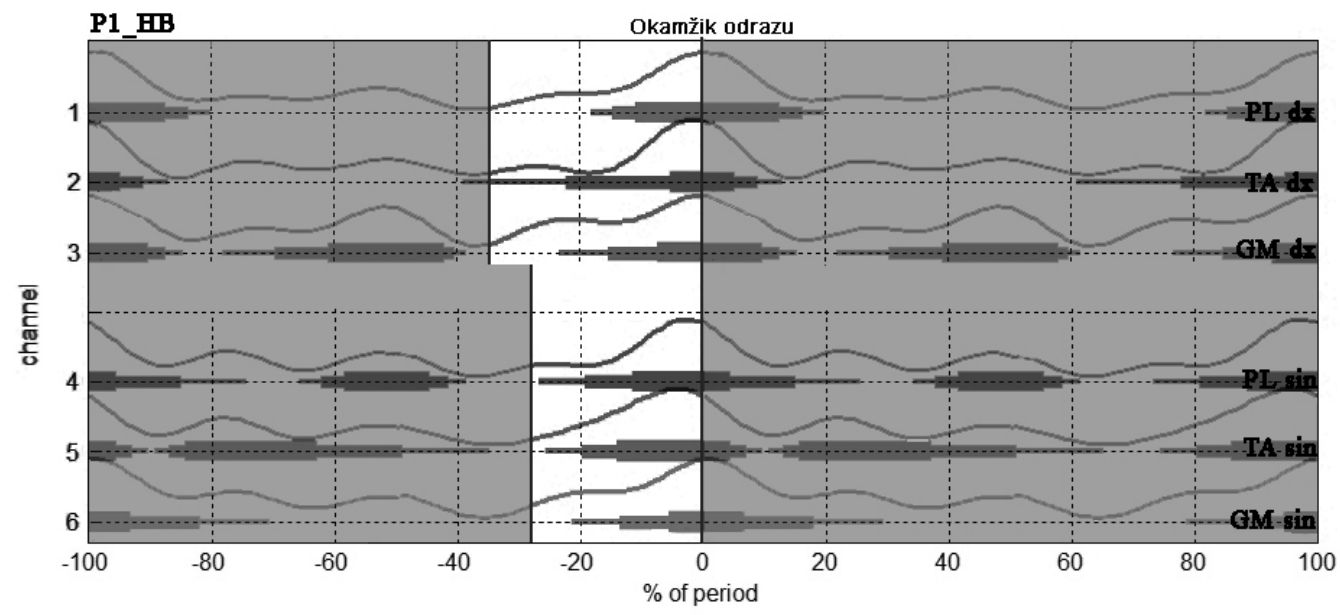

Obr. 2 Graf Boats \& Envelopes průměrného pracovního kroku, který ukazují intervaly významné svalové aktivity a průběh EMG křivky průměrného pracovního cyklu při HB u probanda P1: Boats - vodorovné úsečky: nejslabší úsečka vyznačuje SD nástupu aktivace/deaktivace svalu; 2. a 3. vnitřní úsečka vyznačují interval uznatelné aktivity svalu. Envelopes - průběh EMG křivky průměrného pracovního cyklu. Kontinuální svislice vymezuji sledovaný interval odrazu dle definovaných kličových míst pohybu: svislice v $0 \%$ vyznačuje okamžik dokončeni odrazu, druhé dvě pak okamžik začátku významné aktivace.

Grafy Boats \& Envelopes pak doplňují další grafy (obrázek 3 a obrázek 4), které vyznačují délku aktivace svalů, která přímo souvisí s odrazem. Odraz nastává v hodnotě 0 . Úsečky ukazují délku aktivace před odrazem. Délka aktivace je vyjádřena procentuálně vzhledem k délce průměrného krokového cyklu. Interval aktivace TA je orientován do záporných hodnot, protože jako jediný 
sval se většinou aktivuje až po odraze. Pro ukázku laterality jsou pod sebou vyneseny hodnoty délky aktivace levé ( $\sin )$ a pravé $(\mathrm{dx})$ dolní končetiny.

\section{P1_CL_DS: Délka zapojení svalu od začátku jeho aktivace do okamžiku dokončení odrazu (\%)}

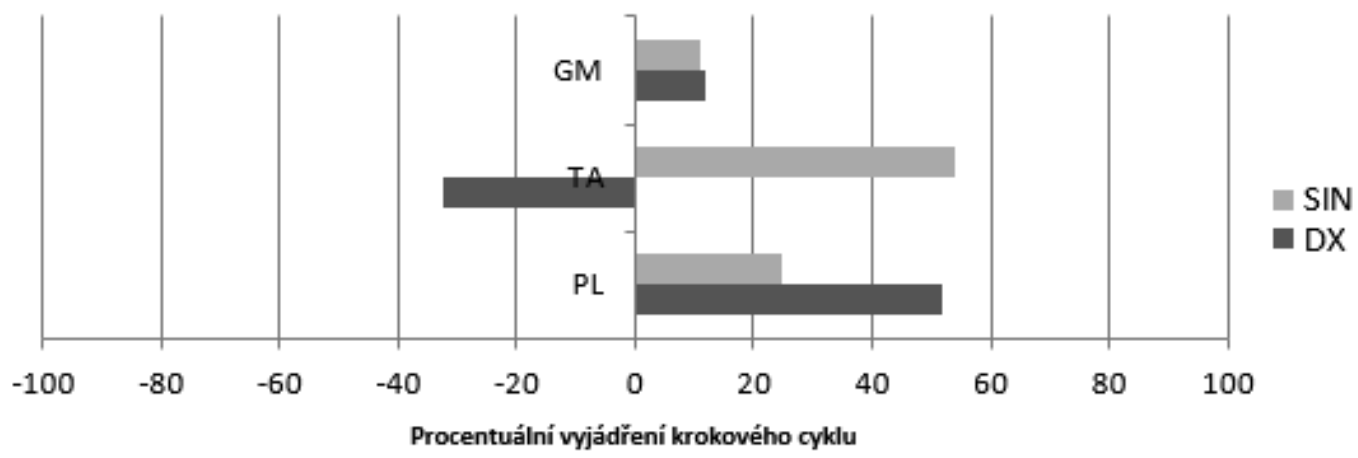

Obr. 3 Graf délky zapojení svalu od začátku jeho aktivace do okamžiku dokončení odrazu (\%) při CL_DS u probanda P1; sin - levá DK; dx - pravá DK. Odlišná časová orientace TA byla zmíněna výše.

Ze statistických výsledků lze usuzovat na vysokou laterální intralokomoční podobnost (viz Tabulka 2) klasické techniky (DS) i stromečku (HB) u všech probandů.

\section{P1_HB: Délka zapojení svalu od začátku jeho aktivace do okamžiku}

dokončení odrazu (\%)

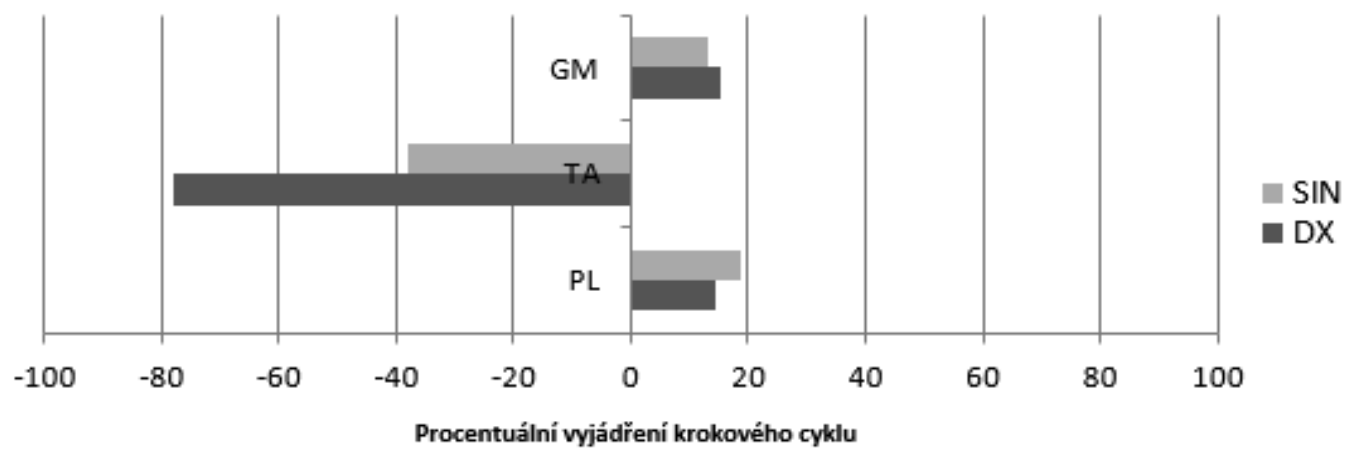

Obr. 4 Graf délky zapojení svalu od začátku jeho aktivace do okamžiku dokončení odrazu (\%) při HB u probanda P1; sin - levá DK; dx - pravá DK. Odlišná časová orientace TA byla zmíněna výše.

Tab. 2: Porovnání laterální délky aktivace měřených svalů vzhledem k dokončení odrazu při $C L$ a $H B$ za použití metody ANOVA1 pro hladinu $a=0,05$

\begin{tabular}{|c|c|c|c|c|c|c|}
\hline Sval & \multicolumn{3}{|c|}{ DS dx_sin } & \multicolumn{3}{c|}{ HB dx_sin } \\
\hline & F & Hodn. P & F krit & F & Hodn. P & F krit \\
\hline PL & 3,679 & 0,079 & 4,747 & 1,169 & 0,301 & 4,747 \\
\hline TA & 1,624 & 0,227 & 4,747 & 1,888 & 0,195 & 4,747 \\
\hline GM & 0,010 & 0,924 & 4,747 & 2,699 & 0,126 & 4,747 \\
\hline
\end{tabular}


Tab. 3: Průměrná délka intervalu (\%) aktivace svalů před odrazem

\begin{tabular}{|c|c|c|c|c|c|}
\hline \multicolumn{2}{|c|}{ Sval } & DS dx & HB dx & DS $\sin$ & HB sin \\
\hline PL & Průměr & 39,914 & 23,200 & 26,334 & 17,129 \\
\hline & SD & 14,265 & 12,450 & 7,724 & 3,258 \\
\hline TA & Průměr & 25,174 & 28,921 & 23,408 & 26,829 \\
\hline & SD & 8,634 & 9,412 & 14,643 & 21,966 \\
\hline GM & Průměr & 16,621 & 15,318 & 17,061 & 17,707 \\
\hline & SD & 4,477 & 1,534 & 9,272 & 2,959 \\
\hline
\end{tabular}

U P1 při klasické technice je TA na levé DK aktivován již před odrazem, zatímco na levé straně dochází $\mathrm{k}$ významné aktivaci až po odrazu.

Tab. 4: Interlokomoční porovnání doby trvání aktivace sledovaných svalů v souvislosti s dokončením odrazu při obou způsobech běhu na lyžích s použitím statistiky ANOVA1 pro hladinu $a=0,05$

\begin{tabular}{|c|c|c|c|c|c|c|}
\hline \multirow{2}{*}{ Sval } & \multicolumn{3}{|c|}{ DS × HB dx } & \multicolumn{3}{c|}{ DS × HB sin } \\
\cline { 2 - 7 } & F & Hodn.P & F krit & F & Hodn.P & F krit \\
\hline PL & 4,09 & 0,07 & 4,75 & 6,33 & 0,03 & 4,75 \\
\hline TA & 1,52 & 0,24 & 4,75 & 0,26 & 0,62 & 4,75 \\
\hline GM & 0,40 & 0,54 & 4,75 & 0,02 & 0,88 & 4,75 \\
\hline
\end{tabular}

Tabulky 3 a 4 uvádějí výsledky statistiky ANOVA1 porovnávající statistickou významnost v době trvání aktivace měřených svalů přímo související s odrazem. Ve všech případech intralokomočního porovnání HB vs. DS na pravé DK byla nalezena statistická významnost. V jediném případè levé DK byla domněnka o podobnosti odrazové fáze obou způsobů běhu popřena, a to při srovnání HB a DS, kdy byla nalezena hodnota F-statistiky $(6,330)$ vyšší než hodnota F-krit. $(4,747)$ u PL sin.

\section{DISKUZE}

Schopnost neuromuskulární koordinace považuje Hébert-Losier a kol. (2017) pro elitní výkony při sprintu na lyžích za velmi důležitou determinantu výkonu.

Průměrná perioda kroku při sklonu stoupání $10^{\circ}$ trvala $1,20 \mathrm{~s}$ při DS a $0,81 \mathrm{~s}$ př́i HB. Chrástková a kol. (2013) zjistili trvání průměrného krokového cyklu při DS 1,36 s. Norman a Komi (1987) při $9^{\circ}$ stoupání naměřili frekvenci průměrného kroku při DS $1,3 \mathrm{~Hz}, \mathrm{z}$ čehož časový úsek $0,77 \mathrm{~s}$, Norman a kol. (1989) ve stoupání $12^{\circ}$ taktéž pro klasickou techniku frekvenci $1,09 \mathrm{~Hz}$, což odpovídá 0,92 s a Bilodeau a kol. (1992) při $5^{\circ}$ stoupání $0,85 \mathrm{~Hz}$ a 1,18 s (Bilodeau, Boulay, \& Roy, 1992). Anderson (2011) logicky popisuje, že trvání průměrného kroku při HB do stoupání $15^{\circ} \mathrm{s}$ rychlostí jízdy klesá, a to z $0,85 \mathrm{~s}$ při $65 \%$ maximální rychlosti $\mathrm{k} 0,63 \mathrm{~s}$ v maximu.

Časový úsek pracovního cyklu závisí na rychlosti jízdy. Rychlost jízdy závisí na intenzitě svalové aktivace a je samozřejmě ovlivněna vnějšími podmínkami, jako je profil tratě, sněhové podmínky, úprava lyží, apod. (Gnad \& Psotová, 2005). Smith \& Nelson (1990) popisují nárůst rychlosti spíše na základě zvýšení frekvence cyklů, než změnou délky kroku.

Změny v aktivaci svalů dolní končetiny, které jsou více fázické (GM, TA), popisují při různých formách běhu na lyžích (DS a V-1, tedy bruslení oboustranné jednodobé) v porovnání s volnou bipedální chůzí Chrástková a kol. (2011). Při chůzi a běhu na lyžích se naopak velice podobně zapojovaly svaly, které jsou více posturální (m. gluteus medius). Z toho plyne, že chůzový stereotyp udržení posturální stability se přenáší do stereotypu běhu na lyžích s vysokou mírou shody. Při 
běhu na lyžích byla u svalu TA nalezena vyšší posturální úroveň v oporovém postavení ve skluzu na jedné lyži v porovnání s chůzí, kde TA vykazuje více fázický průběh aktivace (při chůzi se ploska nohy dynamicky odvíjí po podložce, zatímco tato situace při skluzu na jedné lyži chybí).

Aktivace svalů dolní končetiny s vyšší rychlostí vzrůstá. Vyšší míru aktivace tak nalezli např. Vahasoyrinki a kol. (2008) ve fázi odrazu.

Véle (2006) uvádí, že bezpečná chůze po nerovném pevném povrchu je možná pouze při zajištěné stabilizaci vzpř́mené polohy těla, a to v klidu i v pohybu. Toho dosahuje CNS za pomoci svalového aparátu, avšak za předpokladu takové pevné opory v místě kontaktu s opornou bází na podložce, která zajistí působení reaktivní síly. Ta vzniká vektorovým součtem gravitační a propulzní svalové síly. Nestera a kol. (2007) a podobně Chrástková a kol. (2013) uvádějí, že při běhu na lyžích se jedná o chvilkové udržování postury v rovnovážném postavení na jedné lyži, která je ale ve skluzu. To není pro lidskou lokomoci (chůzi, běh) prrirozené (Kračmar, Chrástková, Bačáková \& kol., 2016).

Při běhu na lyžích klasickou technikou vzniká punctum fixum pouze na nepatrný okamžik, a to v místě kontaktu s opornou bází. Lyžař musí být schopen správného načasování maximálního zatížení lyže (Gnad \& Psotová, 2005; Ilavský \& Suk, 2005), aby vytvořil potřebnou reaktivní sílu pro realizaci odrazu a pohyb pokračoval vpřed. Tato skutečnost spekulativně ukazuje na rozdílnost pohybového stereotypu chůze a běhu na lyžích klasickou technikou, a to především ve fázi opory. Na lyžích je skluz žádoucím fenoménem, naopak u chůze a u atletického běhu fenoménem nežádoucím.

Chrástková a kol. (2013) se odkazují na Kračmara (2002), který uvádí, že při běhu na lyžích probíhá pohyb těžiště v sagitální rovině (stejně jako u chůze). To aktualizují Kračmar, Chrástková, Bačáková a kol. (2016). Dále uvádějí, že výraznější laterolaterální pohyb ve frontální rovině (na rozdíl do chůze) zajištuje dostatečné přenesení hmotnosti těla nad skluzovou lyži tak, aby bylo zajištěno bezpečné jednooporové postavení pro optimální skluz na jedné lyži. Vyžaduje to pocitovou lokalizaci průběhu místa největšího tlaku na laterální části plosky nohy, což opět vede ke stavu posturálního dyskomfortu u koordinačně nevyspělých lyžařů.

\subsection{M. peroneus longus (PL)}

Při hodnocení délky aktivity svalu PL při klasické technice před dokončením odrazu lze konstatovat, že byl interval aktivace na pravé dolní končetině lyžaře delší než na levé pouze ve třech prrípadech ze čtrnácti. Vypovídá to o stabilizační funkci tohoto svalu při skluzu, zatímco při chůzi pracuje ve fázickém režimu při zvedání špičky nohy při nákroku.

Dvouvrcholová aktivace při DS svalu PL byla zjištěna ve dvou případech ze čtrnácti. Jednalo se o levou stranu. V interindividuálním porovnání se PL dx aktivuje 39,9\% před odrazem oproti $26,3 \% \mathrm{PL}$ sin v rámci průměrného sledovaného úseku (tabulka 3). Spekulace o dominantní nebo preferované končetině, o neměřitelném minimálním sklonu příčného profilu trati, případně o laterálně rozdílné kvalitě sněhové pokrývky jsou mimo rozsah tohoto sdělení.

Při HB je aktivace PL čistě fázická, protože charakter pohybu je velmi podobný jako při chůzi, resp. prri atletickém běhu, zatímco při formách běhu na lyžích, které skluzovou fázi mají, přebírá PL i funkci posturální. Na základě aktivace tohoto svalu lze hodnotit úroveň dynamické rovnováhy jezdců - čím nižší tato schopnost je, tím hůře PL dosahuje relaxace. To ukazuje velikost směrodatných odchylek nástupů aktivace a deaktivace PL (viz grafy Boats \& Envelopes, např. graf na obrázku 2). Jak uvádí Petrovický a Doskočil (1995), šlacha PL významně podpírá podélnou i přičnou klenbu nožní. Pokud tedy není ploska nohy pevně na podložce, musí být PL stále aktivní, aby byla zachována stabilita. Tato situace se při běhu na lyžích ve skluzové fázi vyskytuje stále, nebot̉ skluz CNS vnímá jako smykový posturální dyskomfort, při kterém hrozí potenciální nebezpečí přepadnutí do strany a při kterém nemůže být vytvořeno pevné místo opory. 
PL ve spolupráci s m. peroneus brevis je plantárním pronátorem (zvedá vnější okraj nohy) a napomáhá plantární flexi a abdukci nohy (Petrovický \& Doskočil, 1995). Tato jeho funkce je $\mathrm{z}$ pohledu běhu na lyžích velmi důležitá pro odraz v odvratu při HB. Ten je prováděn $\mathrm{z}$ vnitřní hrany lyže, vlastně i z vnitřní hrany plosky nohy, zatímco vnější hrana je nad podložkou.

Při analýze laterality při HB byla déle trvající aktivita PL dx než PL sin nalezena pouze ve dvou př́padech ze čtrnácti, kdy se zároveň jednalo o významný rozdíl ve velikosti aktivačního intervalu: $52 \%$ vs. $13 \%$ a $34 \%$ vs. $14,5 \%$ pracovního cyklu. U ostatních pěti probandů se laterální rozdíl v délce aktivity pohyboval v rádu procent (do $8 \%$; viz grafy Délka aktivace svalů, grafy na obrázcích 3 a 4).

Při srovnání laterality ukázaly tři případy ze čtrnácti významné rozdílnosti v aktivaci PL před odrazem na pravé dolní končetině $17,7 \%$ oproti $55,7 \%$ na levé, ve druhém případě se jedná o hodnoty $43,4 \%$ vs. $62,6 \%$ a $25,0 \%$ vs. $52,0 \%$ (graf na obrázku 3). Delší časový interval aktivace PL před odrazem byl nalezen na levé straně, což může být podmíněno mírným, neměřitelným ukloněním svahu na levou stranu nebo rozdílnou kvalitou sněhové pokrývky, a tudíž potřebou vytvoření větší posturální stability na této straně i v upravené stopě. Přesné geografické zaměření terénu bylo mimo možnosti projektu. Ostatní případy vykazují laterální rozdíly jen minimální do $5 \%$. Délka svalové aktivace přímo související s odrazem se pohybuje v hodnotách od $17,7 \%$ do $32,2 \%$. Výjimky tvoří již zmíněné prrípady levé dolní končetiny, v nichž byl interval aktivace překročen oběma dolními končetinami (43,4\% a 62,6 \%).

\subsection{M. tibialis anterior (TA)}

Funkcí TA je především dorsální flexe nohy se současnou supinací nohy (dorsální flexe a inverze nohy). Pokud stojí noha pevně na podložce, pak TA spolu s m. extensor hallucis longus a m. extensor hallucis brevis ohýbá v talokrurálním kloubu bérec dopředu (Petrovický \& Doskočil, 1995). Zároveň TA udržuje podélnou klenbu nohy a je maximálně aktivován při chůzi (Dylevský, Druga, \& Mrázková, 2000) ve fázi nákroku. Schopnost dorsální flexe nohy je při běhu na lyžích nepostradatelnou ve fázi přenosu (Gertsch, Borgeat, \& Wälli, 1987) a při stabilizaci polohy kolene ve fázi skluzu (Smith, 1992). Při běhu na lyžích je svalem více posturálním, podílejícím se na udržování dynamické rovnováhy ve skluzu na jedné lyži v kooperaci s posturálními antagonisty na dorzální straně bérce.

Při klasickém běhu na lyžích TA vykazuje aktivitu v okamžiku odrazu pouze u dvou probandů (jedná se o odpověd’ funkčního antagonisty na aktivaci GM). Ve zbylých prŕpadech je v této době relaxován. Jedná se podobně jako u PL o schopnost relaxace dle míry dokonalosti dynamické rovnováhy. Fázi relaxace stř́ídá nástup aktivace pro následnou stabilizaci nohy po dokroku. V př́padě jednoho probanda byla aktivita TA na pravé dolní končetině až po odrazu, zatímco TA sin tohoto probanda se zapojuje již před odrazem (graf na obrázku 3). TA vykazuje v rámci celého krokového cyklu dvouvrcholovou aktivitu v sedmi případech z celkových 14 .

Při HB přetrvává aktivita TA i po odrazu. Ve čtyřech případech nastává lokální maximum těsně před odrazem, ve třech případech relaxuje a v jednom případě jeho aktivita vzrůstá. $V$ osmi př́padech byla nalezena dvouvrcholová aktivita. Při HB je oproti DS výrazné stř́iání fáze aktivace a relaxace. HB se nejvíce podobá běhu, který je starý cca 2 mil. let (Lieberman, 2013; Kračmar, Chrástková, Bačáková, \& kol., 2016). Smyk, který je řízeně realizován ve skluzové fázi, je pro lidskou lokomoci nepřirozeným fenoménem.

Skluzovou fází v průběhu krokového cyklu při DS je podmíněn posturální charakter práce TA, zatímco tato fáze při $\mathrm{HB}$ chybí, a proto se zde výrazně stř́idá fáze aktivace a relaxace.

Při běhu na lyžích se TA dostává do funkce posturálního zajištění rovnováhy především v sagitální rovině. Při chůzi TA zajištuje pouze dorzální flexi pro umožnění přenosu DK ve fázi nákroku, aby člověk nezakopl (Chrástková \& kol., 2013). Při DS k této situaci nemůže díky lyži dojít, proto 
podobný požadavek pro fázickou činnost nemá opodstatnění. Špička odrazové lyže je upravenou stopou regulována do přímého směru a po sněhu klouže po ploše skluznice. Proto zakopnutí jako při chůzi nepřipadá v úvahu, což však neplatí pro HB, kde jsou lyže v odvratu. Zde musí TA a PL po odrazu špičku nohy přizvednout, a to ve směru od malíkové hrany plosky nohy, odraz je totiž prováděn $\mathrm{z}$ vnitřní hrany lyže. $\mathrm{K}$ tomu ještě musí být přizvednuta i dlouhá a oproti chůzi nebo běhu relativně těžká špička lyže. Pokud se to nepodaří, musí být lyže na sníh položena předčasně a může hrozit až zakopnutí o vnitřní hranu lyže.

Chrástková a kol. (2013) ve své studii zahrnuli PL a TA do jedné anatomickofunkční skupiny a funkci obou svalů hodnotí dohromady. Ukázalo se, že oba svaly při běhu na lyžích DS zastávají funkci fázicko-posturální, na což poukazuje jak vícevrcholová aktivace (dvě až tři lokální maxima v rámci průměrného pracovního cyklu), tak i autokorelační koeficienty, směrodatné odchylky a další charakteristiky počátků nástupu uznatelné aktivace. Myšlenka jednoho funkčního celku PL a TA je zeslabena skutečností, že odraz při DS je proveden z plochy lyže, zatímco při HB z hrany.

Laterální rozdíly velikosti intervalů aktivace jsou hodnoceny jako výrazné. Pouze u jediného probanda byl laterální rozdíl TA u obou způsobů běhu $1 \%$, ostatní probandi vykazovali minimální rozdíl $9 \%$ a více. Byla zjištěna vysoká variabilita aktivace TA u téměř celého sledovaného souboru. Na základě těchto šetření lze rovněž usuzovat na lyžařovu schopnost udržovat dynamickou rovnováhu a koordinaci. Delší interval aktivace samozřejmě zvyšuje energetickou náročnost, nedojde $\mathrm{k}$ dostatečné relaxaci svalu, a tak únava svalu musí nastoupit dříve. Variabilita svalové aktivace relativně velmi slabého svalu TA (při chůzi pouze zvedá špičku nohy) ukazuje rovněž na důležitou úlohu tohoto svalu u lidské bipedální lokomoce, kam se DS a HB nepochybně řadí. Není to výkonný lokomočně propulzní sval, ale rozhoduje o kvalitě chůze a běhu a samožrejmě i běhu na lyžích. Reaguje proto na nejmenší terénní nerovnosti, př́ípadně na nepostřehnutelný a na sněhové pokrývce $\mathrm{v}$ zásadě neměřitelný vrstevnicový sklon terénu.

$\mathrm{V}$ délce aktivace měřených svalů přímo související s odrazem ve všech případech intralokomočního porovnání klasické techniky a „stromečku“ na pravé DK byla nalezena statistická významnost. $V$ jediném př́padě levé $\mathrm{DK}$ byla domněnka o podobnosti odrazové fáze obou způsobů běhu popřena, kdy hodnota F-statistiky $(6,330)$ byla vyšší než hodnota F-krit. $(4,747)$ u PL sin. Ze statistických výsledků lze usuzovat na vysokou laterální intralokomoční podobnost klasické techniky $(\mathrm{CL})$ i stromečku $(\mathrm{HB}) \mathrm{u}$ všech probandů.

Za vysvětlení zjištěných výsledků můžeme považovat odlišný charakter neodrazové fáze kroku. Při HB („stromečku“) se nevyskytuje fáze skluzu, která vyžaduje posturální charakter práce svalů. Udržování dynamické rovnováhy při skluzu mění funkci převážně fázických svalů do funkce fázicko-posturální. Vysoce výkonní běžci na lyžích jsou schopni v průběhu krokového cyklu běhu na lyžích i relaxovat, což nám potvrdila analýza svalů $\mathrm{m}$. tibialis anterior či m. peroneus longus.

\subsection{M. gastrocnemius-caput medialis (GM)}

Tabulka jasně ukazuje fázickou práci GM. To potvrzuje oprávněnost volby tohoto svalu za referenční a pro odraz rozhodující.

SD interval od začátku nástupu aktivace do dosažení jejího maxima - proběhnutí odrazu je vzhledem k ostatním svalům minimální (max. 9,27 v případě DS na levé DK) a při obou sledovaných způsobech běhu na lyžích trvá přibližně stejně dlouho. U obou sledovaných způsobů běhu jsme nalezli výrazně fázickou funkci GM. Pouze ve třech př́padech ze čtrnácti u každého způsobu byl zjištěn dvouvrcholový průběh aktivity tohoto svalu. Jeho funkce je stejná jako při chůzi a běhu - zvednout protilehlou polovinu pohybové soustavy pro nákrok do dalšího lokomočního cyklu.

S rychlostí ale nevzrůstají průměrné hodnoty záznamu EMG signálu pro sval GM ve fázi odrazu, což Vahasoyrinki a kol. (2008) vysvětlují funkcí GM zastavit lyži. Náš odlišný názor je 
uveden v poslední větě předchozího odstavce. Jako excentrickou charakterizují Chrástková a kol. (2013) práci m. triceps surae, jenž vyvíjí sílu, která přesahuje hmotnost těla, posunuje je převážně vzhůru a v podmínkách dynamické rovnováhy téměř nepodstatně vpřed (Véle, 2006; Kračmar, Chrástková, Bačáková, \& kol., 2016). Aktivita GM byla i zde vyhodnocena jen jako jednovrcholová. Laterální porovnání aktivace GM ukazuje, že GM dx a sin se aktivují ve vzájemném fázovém posunu 51 \% při volné bipedální chůzi, 50 \% při DS (Chrástková, Bačáková, Kračmar, \& Hojka, 2011), což ukazuje vysokou laterální symetrii timingu.

Dylevský a kol. (2000) zjištují, že funkce dvoukloubového svalu GM je složitější. Společně $\mathrm{s}$ m. soleus (dohromady tvoří triceps surae) jsou rozhodujícím flexorem nohy (plantární přitažení špičky) s mírnou supinací a addukcí. Funkce GM je spíše dynamická (chůze), zatímco m. soleus je více svalem posturálním (stoj). Pro chůzi je GM nepostradatelný, nebot odvíji patu a poté plosku nohy od podložky, zvedá př́slušnou stranu pánve a dolní končetinu pro nákrok a umožňuje stoj na špičkách a výpon (Petrovický \& Doskočil, 1995). Přestože je GM dvoukloubový sval, jeho podíl na flexi kolena je díky pákovým poměrům minimální (Dylevský, Druga, \& Mrázková, 2000). Dle našeho názoru je jeho úpon na stehně nikoliv z důvodů flexe kolena, ale pro lepší pákové poměry pro funkci tohoto svalu. Po zvednutí dolní končetiny po odrazu zvedá GM i pánev a laterálně př́slušnou část trupu tak, aby byl $\mathrm{m}$. gluteus medius schopen pánev bilaterálně udržet ve vodorovném postavení. Pro nakročení pak spolupracuje s TA.

\section{ZÁVĚR}

Naše studie se soustředila na vybranou část svalů dolních končetin, které zásadně ovlivňují postavení nohy především v sagitální rovině. Studie vycházela z předpokladu (Kračmar, Chrástková, Bačáková, \& kol., 2016), že běh na lyžích klasickou technikou oboustranným odvratem (,stromeček“, HB) a běh na lyžích dvoudobý stř́idavý (DS) je velmi blízkou paralelou přirozené lidské lokomoce prostřednictvím pletence pánevního (volná bipedální chůze a běh).

Statistická významnost shody pohybového vzoru byla shledána ve všech prrípadech intralokomočního porovnání běhu oboustranným odvratem s klasickou technikou během dvoudobým stř́idavým na pravé dolní končetině. Na levé dolní končetině byl však předpoklad podobnosti odrazové fáze daných lokomocí popřen. Byt se jednalo o jeden jediný sval na levé dolní končetině $\mathrm{z}$ celého sledovaného souboru, logicky to vzbuzuje vědecké pochybnosti z hlediska jednoznačných závěrů. Souvislost s nemožností přesně sledovat příčný sklon trati byla zmíněna v diskuzi. Zde by bylo možno dále hledat určitý další výklad situace: Přri komparaci aktivace svalů při odrazu při běhu na lyžích oboustranným odvratem (HB) a při technice klasické během dvoudobým střídavým (DS) byla nalezena hodnota F-statistiky $(6,33)$ vyšší než hodnota F-krit. $(4,75)$ u m. peroneus longus sin. Za vysvětlení zjištěných výsledků můžeme považovat odlišný charakter neodrazové fáze kroku. Při HB („stromečku“) se nevyskytuje fáze skluzu, která vyžaduje posturální charakter práce svalů. Dalším vysvětlením může být i to, že relativně slabé svaly $\mathrm{m}$. tibialis anterior a m. peroneus longus, které mají při chůzi a běhu pouze zvedat špičku nohy, se nacházejí při běhu na lyžích nikoli ve funkční pozici pouze fázické, ale ve skluzové fázi i posturální. Jemná cizelovaná práce relativně velmi slabých dorzálních flexorů nohy zajisté reaguje na proměnlivý a našimi prostředky neměřitelný příčný profil trati. Relativně velmi silné svaly jako $\mathrm{m}$. gastrocnemius vykazují ve své aktivaci mnohem vyšší míru pravidelnosti a laterální vyváženosti. $Z$ výpočtů pomocí statistiky ANOVA1 lze usuzovat na vysokou laterální míru podobnosti při odrazu při DS i HB. Jedná se ale o dva různé průběhy odrazů. Jeden z plochy lyže, která stojí na místě (HB) a druhý z hrany lyže, která právě ukončuje fázi skluzu (DS). 
Běh na lyžích (DS) se vyznačuje skluzovou fází, v níž je nutné udržovat semiflexi kolena a kyčle (což se u chůze nevyskytuje) a je nutné udržet tělo v dynamické rovnováze. Svaly dolních končetin proto musí reagovat zvýšenou aktivitou v průběhu celého pohybového cyklu. Proto dochází k vyšší míre stabilizace postury při běhu na lyžích obecně, což se blahodárně projevuje na trofické a tonické vyváženosti celé funkčně zřetězené pohybové soustavy. $\mathrm{K}$ benefitům v této studii nesledovaným patří $\mathrm{v}$ této souvislosti i velmi významné propulzní zapojení ramenního pletence, které funkční zřetězení optimalizuje. Díky skluzové fázi svaly, které běžně pracují ve fázickém režimu, vykonávají i funkci posturální. Tato skutečnost je nejvíce patrná u m. tibialis anterior. Částečně arteficiální pohyb (díky nepřirozenému smyku neboli skluzu), kterým běh na lyžích bezesporu je, je na rozdíl od chůze, resp. běhu založen na fenoménu skluzu lyže, kdy pohybová soustava řeší posturální požadavky ve ztížených balančních podmínkách pocitového posturálního dyskomfortu.

Udržování dynamické rovnováhy při skluzu mění funkci převážně fázických svalů do funkce fázicko-posturální. Vysoce výkonní běžci na lyžích jsou schopni v průběhu krokového cyklu běhu na lyžích i relaxovat, což nám potvrdila analýza svalů m. tibialis anterior či m. peroneus longus. Někteří mají tuto schopnost více vyvinutou. Zde nacházíme kapacitu kvalitativního výzkumu založeného na kvantitativních datech, tedy v našem př́ipadě výzkumu koordinace práce pohybové soustavy, v predikci sportovních talentů.

Výsledky výzkumu jsou samozřejmě velmi limitovány, a to jak metodou povrchové elektromyografie, která pouze odhaduje svalovou práci v místě lokalizace elektrody na svalu, tak i počtem probandů. Nicméně i při tomto nízkém počtu probandů posiluje optimismus ohledně interpretace výsledků fakt, že se jedná o výběr nejvýkonnějších sportovců, a tím i o jednu z nejefektivnějších forem sledované lokomoce v České republice v dané věkové kategorii. Jedná se však o jednu z prvních terénních studií, která porovnává průběh odrazu různých forem běhu na lyžích (běh na lyžích dvoudobý střídavý klasickou technikou a běh na lyžích oboustranným odvratem „stromečkem“) z pohledu aktivace vybraných povrchových svalů dolních končetin. Jejich výběr byl podložen poznatky o přirozené lidské lokomoci prostřednictvím pánevního pletence, která je pro nás přirozená - chůzi a běhu.

Uvedené výsledky by měly pomoci pochopit techniku běhu na lyžích ve dvou zkoumaných formách. Určité problémy spojené se standardizací podmínek terénního výzkumu jsou vyváženy faktem, že terénní výzkum in vivo má neocenitelný význam pro svoji autenticitu oproti sterilním podmínkám laboratorního výzkumu bez variability vnějších podmínek. Studie bude mít pokračování ve zkoumání koordinačních vztahů mezi ostatními technikami běžeckého lyžování i jejich vazeb k lokomočním programům volné bipedální chůze a běhu. Teoretický př́nos studie spatřujeme $\mathrm{v}$ potvrzení odlišných charakteristik pohybového chování sledované oblasti pohybové soustavy. Svalová koordinace odrazu se liší, pokud po odraze (z důvodů rozsahu studie nebylo monitorováno) následuje bud' fáze skluzu (DS) nebo fáze opory (HB).

Tato studie vznikla v rámci Programu institucionální podpory vědy na Univerzitě Karlově Progres, c. Q41 Biologické aspekty zkoumání lidského pohybu.

\section{Reference}

Andersson, E. (2011). Biomechanical analysis of the herringbone technique in classical cross-country skiing. Trondheim: Norwegian University of Science and Technology.

Bilodeau, B., Boulay, M. R., \& Roy, B. (1992). Propulsive and gliding phases in four cross-country skiing techniques. Medicine \& Science in Sports \& Exercise, 8, 917-925.

Clifford, P. S. (September 1992). Scientific basis of competitive cross-country skiing. Medicine \& Science in Sports \& Exercise, 24(9), 1007-1009.

Dylevský, l., Druga, R., \& Mrázková, O. (2000). Funkční anatomie člověka. Praha: Grada Publishing. 
FIS. (2012). FIS Cross-coutry homologation manual (6. vyd.). Získáno 2014, z FIS - Interantional Ski Federation: http://www.fis-ski. $\mathrm{com} / \mathrm{mm} /$ Document/documentlibrary/Cross-Country/04/26/87/Homologationmanual2012_VersionJAA4inclcover_ English.pdf

Gertsch, P., Borgeat, A., \& Wälli, T. (1987). New cross-country skiing techniques and compartment syndrome. American Journal of Sports Medicine, 15(6), 612-613.

Gnad, T., \& Psotová, D. (2005). Běh na lyžích. Praha: Karolinum.

Hébert-Losier, K., Zinner, C., Platt, S., Stöggl, T., \& Holmberg, H. C. (2017). Factors that Influence the Performance of Elite Sprint Cross-Country Skiers. Sports Medicine, 47(2), 319-342. doi: 10.1007/s40279-016-0573-2

Chrástková, M. (2014). Kineziologická analýza odrazu při běhu na lyžích. Disertační práce. Praha: UK FTVS.

Chrástková, M., Bačáková, R., Kračmar, B., \& Hojka, V. (2011). Kineziologický obsah vybraných forem běhu na lyžích a volné bipedální chůze. V J. Suchý, \& et al. (Editor), Sciencia Movens, Sborník přispěvků z mezinárodní studentské vědecké konference konané dne 29. března 2011 (s. 285-290). Praha: FTVS UK. Získáno 26. červen 2014, z http://www.ftvs.cuni.cz/ dokumenty/movens/sbornik.pdf

Chrástková, M., Bačáková, R., Špulák, D., Čmejla, R., \& Kračmar, B. (2013). Kineziologická komparace běhu na lyžích klasickou technikou a volné bipedální chůze. Scientia movens 2014. Praha: FTVS UK.

llavský, J., \& Suk, A. (2005). Abeceda běhu na lyžích, metodický dopis. Jablonec nad Nisou.

Kračmar, B. (2002). Kineziologická analýza sportovního pohybu. Praha:Triton.

Kračmar, B., Chrástková, M., Bačáková, R., \& kol. (2016). Fylogeneze lidské lokomoce. Praha: Karolinum.

Lieberman, D. E. (2013). The story of the human body: Evolution, Health, and Disease. Vintage.

Nestera, C. J., Liua, A. M., Ward, E., Howarda, D., Coecheba, J., Derrick, T., \& Patterson, P. (2007). In vitro study of foot kinematics using a dynamic walking cadaver model. Journal of Biomechanics, 9, 1927-1937.

Nilsson, J., Tveit, P., \& Eikrehagen, O. (2004). Effects of Speed on Temporal Patterns in Classical Style and Freestyle Cross Country Skiing. Sports Biomechanic, 3(1), 85-108.

Norman, R. W., \& Komi, P. V. (1987). Mechanical energetics of world class cross-country skiing. International Journal of Sport Biomechanics, 3, 353-369.

Norman, R. W., Ounpuu, S., Fraser, M., \& Mitchell, R. (1989). Mechanical power output and estimated metabolic rates of Nordic skiers during Olympic competition. Journal of Applied Biomechanics, 5(2), 169-184.

Petrovický, P., \& Doskočil, M. (1995). Systematická, topografická a klinická anatomie. 2. dil, Pohybový aparát končetin. Praha: Karolinum.

SENIAM. (10. duben 2014). Získáno 10. duben 2014, z SENIAM: http://seniam.org/

SLČR. (2013). Pravidla lyžařských závodů.

Smith, G. A. (1992). Biomechanical analysis of cross-country skiing techniques. Medicine \& Science in Sports \& Exercise, 24(3), 73-83.

Smith, G. A., \& Nelson, R. C. (1990). Effects of increased velocity on the kinematics of V1 skating in cross country skiing. V E. Kreighbaum, \& A. McNeil (Editor), Biomechanics in Sports IV (pp. 429-438). Bozeman, Montana: Montana State University.

Špulák, D. (2015). Zpracování povrchových elektromyografických signálů. Disertační práce. Praha: České vysoké učení technické v Praze, Fakulta elektrotechnická.

Špulák, D., Čmejla, R., Bačáková, R., Kračmar, B., Satrapová, L., \& Novotný, P. (2014). Muscle activity detection in electromyograms recorded during periodicmovements. Computers in Biology and Medicine, 47, 93-103.

Vahasoyrinki, P., Komi, P. V., Seppala, S., Ishikawa, M., Kolehmainen, V., Salmi, J. A., \& Linnamo, V. (June 2008). Effect of Skiing Speed on Ski and Pole Forces in Cross-Country Skiing. Medicine \& Science in Sports \& Exercise, 40(6), 1111-1116.

Véle, F. (2006). Kineziologie: Přehled klinické kineziologie a patokineziologie pro diagnostiku a terapii poruch pohybové soustavy (2. vyd.). Praha: Triton.

\section{Korespondující autor:}

Martina Chrástková,

UK FTVS, Katedra sportů v prírodě

José Martího 31,

16252 Praha 6-Veleslavín

mchrastkova@ftvs.cuni.cz 